\title{
Evidence for Alteration of the Vitamin D-Endocrine System in Obese Subjects
}

\author{
Norman H. Bell, Sol Epstein, Anne Greene, Judith Shary, Mary Joan Oexmann, and Sheryl Shaw \\ Veterans Administration Medical Center and Departments of Medicine and Pharmacology, Medical University of South Carolina, \\ Charleston, South Carolina 29403; Albert Einstein Medical Center, Philadelphia, Pennsylvania 55901
}

\begin{abstract}
Serum immunoreactive parathyroid hormone (PTH) is increased in obese as compared with nonobese subjects and declines with weight loss. To determine whether alteration of the vitamin $D$ endocrine system occurs in obesity and whether ensuing secondary hyperparathyroidism is associated with a reduction in urinary calcium, a study was performed in 12 obese white individuals, five men and seven women, and 14 nonobese white subjects, eight men and six women, ranging in age from 20 to $35 \mathrm{yr}$. Body weight averaged $106 \pm 6 \mathrm{~kg}$ in the obese and $68 \pm 2$ $\mathrm{kg}$ in the nonobese subjects $(P<0.01)$. Each of them were hospitalized on a metabolic ward and were given a constant daily diet containing $400 \mathrm{mg}$ of calcium and $900 \mathrm{mg}$ of phosphorus. Whereas mean serum calcium, serum ionized calcium, and serum phosphorus were the same in the two groups, mean serum immunoreactive PTH (518 \pm 48 vs. $243 \pm 33$ $\mathrm{pg} / \mathrm{ml}, P<0.001)$, mean serum 1,25-dihydroxyvitamin D $\left[1,25(\mathrm{OH})_{2} \mathrm{D}\right](37 \pm 2$ vs. $29 \pm 2, P<0.01)$, and mean serum Gla protein $(33 \pm 2$ vs. $24 \pm 2 \mathrm{ng} / \mathrm{ml}, P<0.02)$ were significantly higher, and mean serum 25-hydroxyvitamin D (25-OHD) (8 \pm 1 vs. $20 \pm 2 \mathrm{ng} / \mathrm{ml}, P<0.001)$ was significantly lower in the obese than in the nonobese men and women. Mean urinary phosphorus was the same in the two groups, whereas mean urinary calcium $(115 \pm 10$ vs. $166 \pm 13 \mathrm{mg} / \mathrm{d}, P<0.01)$ was significantly lower, and mean urinary cyclic AMP $(3.18 \pm 0.43$ vs. $1.84 \pm 0.25 \mathrm{nM} / \mathrm{dl} \mathrm{GF}, P<0.01)$ and creatinine clearance (216 \pm 13 vs. $173 \pm 6$ liter $/ d, P<0.01)$ were significantly higher in the obese than in the nonobese individuals. There was a significant positive correlation between percentage of ideal body weight and urinary cyclic AMP $(r=0.524, P<0.01)$ and between percentage of ideal body weight and serum immunoreactive PTH $(r=0.717, P<0.01)$ in the two groups. The results provide evidence that alteration of the vitamin $D$ endocrine system in obese subjects is characterized by secondary hyperparathyroidism which is associated with enhanced renal tubular reabsorption of calcium and increased circulating $1,25(\mathrm{OH})_{2} \mathrm{D}$. The reduction of serum $25-\mathrm{OHD}$ in them is attributed to feedback inhibition of hepatic synthesis of the precursor by the increased serum $1,25(\mathrm{OH})_{2} \mathrm{D}$.
\end{abstract}

\section{Introduction}

Available evidence indicates that serum immunoreactive parathyroid hormone $(\mathrm{PTH})^{1}$ is higher in obese than in nonobese

Dr. Bell is a Veterans Administration Medical Investigator. Address reprint requests to Dr. Bell, VA Medical Center.

Received for publication 9 April 1985.

J. Clin. Invest.

(C) The American Society for Clinical Investigation, Inc.

0021-9738/85/07/0370/04 \$1.00

Volume 76, July 1985, 370-373 young adults and declines with weight loss (1). In view of these observations, we carried out an investigation to determine whether obesity modifies the vitamin D-endocrine system and whether secondary hyperparathyroidism is associated with a reduction of urinary calcium in obese subjects.

\section{Methods}

26 normal white subjects were studied. There were 12 obese individuals (five men and seven women) and 14 nonobese subjects (eight men and six women) ranging in age from 20 to $35 \mathrm{yr}$. All of them were hospitalized on the General Clinical Research Center of the Medical University of South Carolina, Charleston, SC. They were given only distilled water to drink and a constant daily diet that was estimated to contain $400 \mathrm{mg}$ of calcium, $900 \mathrm{mg}$ of phosphorus, $18 \mathrm{meq}$ of magnesium, $110 \mathrm{meq}$ of sodium, and $65 \mathrm{meq}$ of potassium. Fasting blood samples were collected for measurement of serum calcium, ionized calcium, phosphorus, magnesium, creatinine, Gla protein, 25hydroxyvitamin D (25-OHD), 1,25-dihydroxyvitamin D [1,25(OH) $)_{2} \mathrm{D}$, and immunoreactive PTH. 24-h urines were collected for measurement of calcium, phosphorus, sodium, potassium, magnesium, creatinine, and cyclic AMP.

Serum and urinary calcium (2), phosphorus (3), creatinine (4), and magnesium (5) were measured by automated colorimetric methods. Serum ionized calcium was measured with a solid state ion electrode. Urinary sodium and potassium were determined by flame photometer. Serum 25-OHD was measured in duplicate at two concentrations by competitive protein binding with vitamin D-deficient rat serum (6) after extraction with acetonitrile, washing with phosphate buffer, chromatography on C-18 Sep-Pak, and elution with acetonitrile (7). 25-OHD was separated from other vitamin D metabolites before the binding assay by chromatography on silica Sep-Pak and elution with hexane-propanol (94:6) (7). Serum $1,25(\mathrm{OH})_{2} \mathrm{D}$ was measured by the method of Reinhardt et al. (7). Serum immunoreactive PTH was measured by radioimmunoassay with a $\mathrm{COOH}$-terminal specific antibody from chicken 77125 at a dilution of 1:10,000 (8). Serum Gla protein was determined by radioimmunoassay (9). Urinary cyclic AMP was measured by radioassay with a binding protein (10). Results are expressed as $\mathrm{nM} / \mathrm{dl}$ glomerular filtrate (GF) (11).

Statistical analyses were performed with nonpaired $t$ test and correlation coefficient by standard methods. The percentage of ideal body weight was determined from tables of the Metropolitan Life Insurance Company, New York.

\section{Results}

Weights of the obese and nonobese subjects averaged $106 \pm 6$ and $68 \pm 2 \mathrm{~kg}$, respectively $(P<0.01)$. The mean age was $26 \pm 1$ yr for the obese and $24 \pm 1$ yr for the nonobese individuals.

The results are summarized in Tables $I$ and II and in Fig. 1. Mean serum Gla protein, mean serum immunoreactive

1. Abbreviations used in this paper: GF, glomerular filtrate; PTH, parathyroid hormone. 
Table I. Serum Values in Obese and Nonobese White Subjects

\begin{tabular}{|c|c|c|c|c|c|c|c|c|}
\hline Subjects & $\begin{array}{l}\text { Serum } \\
\text { calcium }\end{array}$ & $\begin{array}{l}\text { Serum } \\
\mathrm{Ca}^{2+}\end{array}$ & $\begin{array}{l}\text { Serum } \\
\text { phosphorus }\end{array}$ & $\begin{array}{l}\text { Serum } \\
\text { magnesium }\end{array}$ & $\begin{array}{l}\text { Serum } \\
\text { Gla protein* }\end{array}$ & $\begin{array}{l}\text { Serum } \\
\text { iPTH }\end{array}$ & $\begin{array}{l}\text { Serum } \\
25-\mathrm{OHD}\end{array}$ & $\begin{array}{l}\text { Serum } \\
1,25(\mathrm{OH})_{2} \mathrm{D}\end{array}$ \\
\hline & $m g / d l$ & $m g / d l$ & $m g / d l$ & meq/liter & $n g / m l$ & $p g / m l$ & $n g / m l$ & $p g / m l$ \\
\hline Obese (12) & $9.0 \pm 0.1$ & $4.8 \pm 0.1$ & $4.0 \pm 0.1$ & $1.88 \pm 0.02$ & $33 \pm 2$ & $518 \pm 48$ & $8 \pm 1$ & $37 \pm 2$ \\
\hline Nonobese (14) & $9.0 \pm 0.1$ & $4.8 \pm 0.1$ & $3.9 \pm 0.2$ & $1.85 \pm 0.04$ & $24 \pm 3$ & $243 \pm 33$ & $20 \pm 2$ & $29 \pm 2$ \\
\hline$P$ value & NS & NS & NS & NS & $<0.02$ & $<0.001$ & $<0.001$ & $<0.01$ \\
\hline
\end{tabular}

Results are given as mean \pm SE. Figures in parentheses are the number of subjects. * Serum Gla protein was measured in 11 obese and 14 nonobese subjects. ‡ Serum immunoreactive PTH (iPTH) was measured in 12 obese and 13 nonobese subjects.

PTH, and mean serum $1,25(\mathrm{OH})_{2} \mathrm{D}$ were significantly higher in the obese as compared to the nonobese men and women (Table I). Mean serum calcium, serum ionized calcium, serum phosphorus, and serum magnesium were the same in the two groups. Mean serum 25-OHD was significantly lower in the obese than in the nonobese individuals. During the $2 \mathrm{~d}$ on the constant diet, mean urinary calcium was significantly lower in the obese than in the nonobese subjects (Table II). Mean urinary cyclic AMP and creatinine clearance were significantly higher in the obese subjects, and mean urinary phosphorus, potassium, and magnesium were the same in the two groups. As shown in Fig. 1, in all subjects there was a significant positive correlation between percentage of ideal body weight and urinary cyclic AMP $(r=0.524, P<0.01)$. There was also a significant positive correlation between percentage of ideal body weight and serum immunoreactive PTH $(r=0.717, P$ $<0.01$ ).

\section{Discussion}

Bone mass is increased (12-18) and urinary calcium is diminished (19) in black as compared with white individuals. We previously demonstrated increases in mean serum immunoreactive PTH, serum $1,25(\mathrm{OH})_{2} \mathrm{D}$, and urinary cyclic $\mathrm{AMP}$, and confirmed that mean urinary calcium is reduced in normal nonobese blacks (20). Further, the demonstration that the blacks excreted an intravenous calcium load (15 mg calcium/ $\mathrm{kg}$ body weight infused over $8 \mathrm{~h}$ ) as efficiently as whites provided evidence that the reduction in urinary calcium in blacks was caused by increases in circulating PTH and not by primary enhancement of tubular reabsorption of the cation. Mean serum Gla protein, an index of PTH status (21), was lower in blacks than in whites, despite the higher circulating PTH in the blacks. We interpreted these results to indicate that modification of the vitamin D-endocrine system, with enhanced renal tubular reabsorption of calcium and increased circulating $1,25(\mathrm{OH})_{2} \mathrm{D}$ caused by increases in serum PTH, may contribute to the greater bone mass in blacks (20). The larger bone mass in them is attributed to increased muscle mass (13).

The present findings in obese white subjects are similar to the ones obtained by us in nonobese blacks. Thus, obese white individuals show increases in mean serum immunoreactive PTH (1), serum $1,25(\mathrm{OH})_{2} \mathrm{D}$, and urinary cyclic AMP, and decreases in urinary calcium as compared with nonobese white men and women. The reduction of urinary calcium in the obese individuals is all the more evident since it occurred despite an average increase of $24.8 \%$ in creatinine clearance. Obese postmenopausal women were found to have a lower urinary calcium-to-creatinine ratio as compared with nonobese postmenopausal women (22). One difference for which we have no explanation is the reduction of serum Gla protein in blacks in our previous study and the increase of serum Gla protein in the obese as compared with nonobese white subjects, which was seen in the present investigation. We interpret our results to indicate that alteration of the vitamin D-endocrine system also occurs in obesity, and is characterized by secondary increases in circulating PTH with consequent enhanced tubular reabsorption in calcium and increased renal production of $1,25(\mathrm{OH})_{2} \mathrm{D}$.

An alternative explanation for our findings in obese men and women is impaired intestinal absorption of calcium. This possibility appears unlikely, since malabsorption of calcium, if prolonged, would lead to a decline in bone mass. In this

Table II. Urinary Values in Obese and Nonobese White Subjects

\begin{tabular}{|c|c|c|c|c|c|c|c|}
\hline Subjects & $\begin{array}{l}\text { Urinary } \\
\text { calcium }\end{array}$ & $\begin{array}{l}\text { Urinary } \\
\text { phosphorus }\end{array}$ & $\begin{array}{l}\text { Urinary } \\
\text { sodium }\end{array}$ & $\begin{array}{l}\text { Urinary } \\
\text { potassium }\end{array}$ & $\begin{array}{l}\text { Urinary } \\
\text { magnesium }\end{array}$ & $\begin{array}{l}\text { Urinary } \\
\text { cyclic AMP }\end{array}$ & $\begin{array}{l}\text { Creatinine } \\
\text { clearance }\end{array}$ \\
\hline & $m g / d$ & $m g / d$ & meq/d & $m e q / d$ & $m e q / d$ & $n M / d l G F$ & liter/d \\
\hline Obese (12) & $115 \pm 10$ & $1,043 \pm 50$ & $104 \pm 8$ & $62 \pm 3$ & $9.3 \pm 0.9$ & $3.18 \pm 0.43$ & $216 \pm 17$ \\
\hline Nonobese (14) & $166 \pm 13$ & $938 \pm 37$ & $124 \pm 8$ & $62 \pm 4$ & $9.2 \pm 0.4$ & $1.84 \pm 0.25$ & $173 \pm 6$ \\
\hline$P$ value & $<0.01$ & NS & NS & NS & NS & $<0.01$ & $<0.01$ \\
\hline
\end{tabular}

Results are given as mean $\pm \mathrm{SE}$ of the average of two consecutive 24-h urine values in each subject. Figures in parentheses are the number of subjects. 


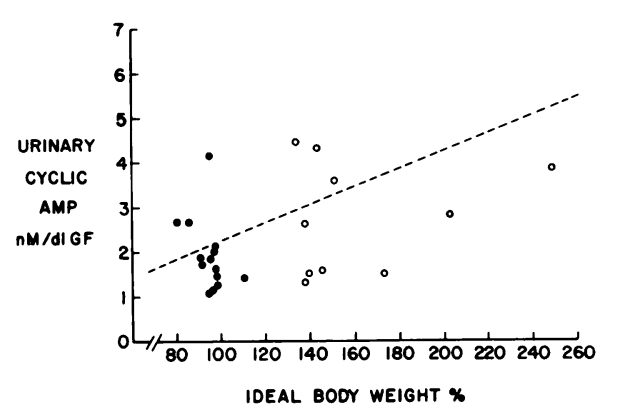

Figure 1. Relationship between urinary cyclic AMP and percentage of ideal body weight in obese and nonobese white subjects. In all of them, there was a significant positive correlation between the two determinations $(r=0.524, P<0.01)$. $\bullet$, nonobese; $\circ$, obese.

regard, measurement of bone mass in obese subjects has yielded conflicting results. Radiographic measurements of metacarpal cortical area showed that skeletal mass was greater in obese than in age-matched nonobese subjects (23). On the other hand, bone mass of the forearm determined by singlephoton absorptiometry demonstrated values that were within the normal range (24). Urinary calcium-to-creatinine ratio in obese postmenopausal women, which was reduced as compared with values in nonobese postmenopausal women, correlated negatively with serum estrogen, and serum estrogens were shown to correlate with body weight (22). It is possible, therefore, that increases in circulating estrogen that occur in obesity because of increased peripheral conversion from androgens, could modify the skeletal response to PTH in obese women (22). It is unlikely, however, that this phenomenon accounts for changes in the vitamin D-endocrine system observed in obese men.

As noted already, increased bone mass in blacks is thought to result from an increased muscle mass (13). If greater strain on the skeleton produced by the increased body weight diminishes the skeletal response to PTH in obesity, the elevated serum immunoreactive PTH should decline with weight loss. Atkinson et al. (1) followed 27 massively obese subjects for periods of up to $1 \mathrm{yr}$ after jejunal-ileal intestinal bypass, and noted that serum immunoreactive PTH decreased with weight loss. Indeed, the reductions in body weight and serum immunoreactive PTH paralleled each other. Thus, at 6 mo after surgery there was a significant correlation between the amount of weight loss, which averaged $44 \mathrm{~kg}$, and the decrease in serum immunoreactive PTH (1).

Mean serum 25-OHD was lower in the obese than in the nonobese subjects. A reduction in mean serum 25-OHD was also found in two other groups of obese individuals, one of which had undergone jejunal-ileal bypass $(24,25)$. In these subjects, there was a progressive increase in serum 25-OHD after surgery to values that were in the normal range. In view of the present findings, and the previously described decline in elevation of serum immunoreactive PTH in association with weight loss after intestinal bypass (1), we attribute the low serum 25-OHD in obese subjects to feedback inhibition of hepatic synthesis of the metabolite by increased circulating $1,25(\mathrm{OH})_{2} \mathrm{D}(26)$. Reversal of obesity and elevated serum immunoreactive PTH would lead to a decline in serum $1,25(\mathrm{OH})_{2} \mathrm{D}$ and allow serum $25-\mathrm{OHD}$ to return to values in the normal range. This explanation would also account for the impaired production of 25-OHD in response to vitamin D challenge described in the obese individuals (24). Low values for serum 25-OHD were also observed in normal nonobese black men and women in whom mean serum $1,25(\mathrm{OH})_{2} \mathrm{D}$ was increased (20). It is likely that reduction of serum 25OHD in them results from impaired dermal production of vitamin $\mathrm{D}$ because of increased skin pigment (27).

\section{Acknowledgments}

We thank Elizabeth Katko for expert secretarial assistance, and the nursing, dietary, and laboratory staffs of the General Clinical Research Center for their contributions.

This work was supported in part by the Veterans Administration and by grant M01 RR 01070 (General Clinical Research Center) from the U. S. Public Health Service.

\section{References}

1. Atkinson, R. L., W. T. Dahms, G. A. Bray, and A. A. Schwartz. 1978. Parathyroid hormone levels in obesity: effects of intestinal bypass surgery. Miner. Electrolyte Metab. 1:315-320.

2. Baginsky, E. S., S. S. Marie, and B. Zak. 1973. Direct microdetermination of calcium. Clin. Chim. Acta. 46:49-54.

3. Fiske, C. H., and Y. Subbarow. 1925. The colorimetric determination of phosphorus. J. Biol. Chem. 66:375-400.

4. Bartels, H., and M. Bohmer. 1971. Eine mikromethode zur kreatinin bestimmung. Clin. Chem. Acta. 32:81-85.

5. Gindler, E. M., and D. A. Heth. 1971. Colorimetric determination with bound "Calgamite" of magnesium in human blood serum. Clin. Chem. 17:662.

6. Dorantes, L. M., S. B. Arnaud, and C. D. Arnaud. 1978. Importance of the isolation of 25-hydroxyvitamin D before assay. J. Lab. Clin. Med. 91:791-796.

7. Reinhardt, T. A., R. L. Horst, J. W. Orf, and B. W. Hollis. 1984. A microassay for 1,25-dihydroxyvitamin $D$ not requiring high performance liquid chromatography: application to clinical studies. J. Clin. Endocrinol. Metab. 58:91-98.

8. Wiske, P. S., S. Epstein, N. H. Bell, S. F. Queener, J. Edmondson, and C. C. Johnston, Jr. 1979. Increases in immunoreactive parathyroid hormone with age. N. Engl. J. Med. 300:1419-1421.

9. Epstein, S., J. Poser, R. McClintock, C. C. Johnston, Jr., G. Bryce, and S. Hui. 1984. Differences in serum bone Gla protein with age and sex. Lancet. II:307-310.

10. Gilman, A. G. 1970. A protein binding assay for adenosine 3',5'-monophosphate. Proc. Natl. Acad. Sci. USA. 67:305-312.

11. Broadus, A. E., J. E. Mahaffey, F. C. Bartter, and R. M. Neer. 1977. Nephrogenous cyclic adenosine monophosphate as a parathyroid function test. J. Clin. Invest. 60:771-783.

12. Trotter, M., G. E. Broman, and R. R. Peterson. 1960. Densities of bones of white and negro skeletons. J. Bone Jt. Surg. Am. Vol. 42A: $50-58$.

13. Cohn, S. H., C. Abesamis, S. Yasamura, J. F. Aloia, I. Zanzi, and K. J. Ellis. 1977. Comparative skeletal mass and radial bone mineral content in black and white women. Metab. Clin. Exp. 26: 171-178.

14. Garn, S. M., S. T. Sandusky, J. M. Nagy, and M. B. McCann. 1972. Advanced skeletal development in low-income Negro children. J. Pediatr. 80:965-969.

15. Owen, G. M., and L. H. Lubin. 1973. Anthropometric differences between black and white preschool children. Am. J. Dis. Child. 126: 168-169.

16. Garn, S. M. 1973. Tendency toward greater stature in American black children. Am. J. Dis. Child. 126:164-166.

17. Garn, S. M., and D. C. Clark. 1975. Nutrition, growth, development and maturation: findings from the ten-state survey 196870. Pediatrics. 56:306-319. 
18. Garn, S. M. 1975. Bone loss and aging. In Physiology and Pathology of Human Aging. R. Goldman, editor. Academic Press, Inc., New York. 39-57.

19. Modlin, M. 1967. Urinary calcium in normal adults and in patients with renal stones: an interracial study. Invest. Urol. 5:49-57.

20. Bell, N. H., A. Greene, S. Epstein, M. J. Oexmann, S. Shaw, and J. Shary. Evidence for alteration of the vitamin D-endocrine system in blacks. J. Clin. Invest. In press.

21. Price, P. A., J. G. Parthemore, and L. J. Deftos. 1980. A new biochemical marker for bone metabolism. J. Clin. Invest. 66:878-883.

22. Frumar, A. W., D. R. Meldrum, G. Geola, I. A. Shamonki, I. V. Tataryn, L. J. Deftos, and H. L. Judd. 1980. Relationship of fasting urinary calcium to circulating estrogen and body weight in postmenopausal women. J. Clin. Endocrinol. Metab. 50:70-75.
23. Dalen, N., D. Hallberg, and B. Lamke. 1975. Bone mass in obese subjects. Acta Med. Scand. 197:353-355.

24. Teitelbaum, S. L., J. D. Halverson, M. Bates, L. Wise, and J. G. Haddad. 1977. Abnormalities of circulating 25-OH vitamin D after jejunal bypass for obesity: evidence of an adaptive response. Ann. Intern. Med. 86:289-293.

25. Rickers, H., C. Christiansen, I. Balslev, and P. Rodbro. 1984. Impairment of vitamin $\mathrm{D}$ metabolism and bone mineral content after intestinal bypass surgery. Scand. J. Gastroenterol. 19:184-189.

26. Bell, N. H., S. Shaw, and R. T. Turner. 1984. Evidence that 1,25-dihydroxyvitamin $D_{3}$ inhibits the hepatic production of 25 hydroxyvitamin D in man. J. Clin. Invest. 74:1540-1544.

27. Clemens, T. L., J. A. Adams, S. L. Henderson, and M. F. Holick. 1982. Increased skin pigment reduces the capacity of the skin to synthesize vitamin D. Lancet. I:74-76. 